\title{
THE EFFECT OF WIDE PUSH-UP EXERCISE AND NARROW PUSH-UP EXERCISE AGAINST STRENGTH, POWER, AND ENDURANCE
}

\author{
Nasiruddin Tamimi*, Dr. EdyMintarto, M. Kes**, \\ Dr. NiningWidya K., M.Appl.Sc.*** \\ UniversitasNegeri Surabaya \\ Universitas Negeri Surabaya \\ Universitas Negeri Surabaya \\ narutamimi@gmail.com*
}

\begin{abstract}
Abstrack
This study aims to improve the level of physical condition, so it can be known and become an evaluation for the sport that achieves a better achievement later. The application of exercises used to improve physical condition is through wide push-ups and narrow push-ups in students of XI IPA in SMA N 1 Sumberrejo Bojonegoro. The type of research used in this study is quantitative with quasi experimental methods (Quasi Experiment). The design used to group research subjects is Matching-Only Design. In this design there are three groups, namely wide push-up exercise group, narrow push-up exercise group, and one control group. Furthermore, the three groups were given a pretest to determine the initial state is there any difference between the experimental group and the control group. After 8 weeks of practice with frequency 3 times a week, then posttest to the three groups to know the effectiveness of the exercise. In the wide push-up exercise group, there was an increase in strength by an average of $2.65 \mathrm{~kg}$, power of 16.92 Joules, and endurance of 2.9 Times. In the narrow push-up exercise group obtained the results of an increase of $3.65 \mathrm{Kg}$ of power, power of 27.91 Joule, and endurance of 3.65 Times. While in the control group obtained the results of an increase of $0.75 \mathrm{Kg}$ of power, power of 4.39 Joule, and endurance of 0.85 Times.Based on the results of research and discussion as described in the previous chapters, it can be concluded that there is a significant influence on the wide pushup exercises on the increase of strength, power, and endurance, there is a significant influence on the exercise of narrow push-up against increased power, power, and endurance, and there are significant differences in influence between wide push-up and narrow push-up exercises for increased strength, power, and endurance
\end{abstract}

Keywords: Wide push-up exercise, narrow push-up, strength, power, endurance

Exercise is an activity that is often done by humans because it has many positive benefits for both body and spirit. In general, exercise is an activity that is done to improve body fitness and maintain body health. Understanding sports as 
described in Act No. 3 of 2005 Chapter I Article (1), Sport is all systematic activities to encourage, nurture, and develop physical, spiritual, and social potential.

Exercise is one of the most influential processes to gain an achievement because that is where all the physical qualities begin to be improved and an athlete's skills begin to be developed. According to Christina (2013, p.46), "exercise is a systematic exercise for a considerable period of time and progressively enhanced and individualized that leads to a change in the features of human psychological functions to achieve predetermined goals." Meanwhile, according to Venkatachalapathy $(2015$, p.2), "the exercise is an organized process through a planned and systematic arrangement of performance and performance preparedness that aims for the perfection of sport and the improvement of the ability of an actual match or a sports competition". Based on the above opinion it can be understood that the exercise is a physical activity that is done systematically, programmed with scientific principles that aim to gain an increase in ability to the activities undertaken or in a sporting event.

Physical condition is a very important element almost throughout the sport. The main purpose of preparing physically is to assist the athlete in improving his skills and achievements to the maximum extent possible. While the purpose of training other physical conditions is to maintain health and perform daily activities with full energy. Physical condition components include: strength, endurance, agility, agility, explosive power, speed, balance, coordination, accuracy, and reaction (Nurhasan, 2011, p.19). Therefore the physical condition exercise needs to get serious attention planned carefully and systematically so that the level of physical fitness and functional ability of the body tools to be better..

Strength, power, and endurance of the arm muscles are the most influential components of successful athletes, especially in sports that require upper body movements, such as arm blows to martial arts. Strength and power to do a powerful blow in a fast time. While the endurance needed to do the punches many times in a longer time.

Many different forms of exercise are used to train strength, power, and endurance of arm muscles. One of the most widely used exercises at the moment is Push-up. Push-up is a well-known exercise to gain strength in the muscles of the upper arm and body. Today's push-up exercises are still commonly used by sports teachers as well as trainers in various sports to train upper body strength on students or athletes. With the development of the current era Push-up is not only used for strength training alone, but to develop other power-related biomotor components, such as power and endurance in arm muscles. The goal of strength development is to meet certain needs in sports or in other words to develop strength or a combination of strength with other abilities to improve athlete performance to the highest possible level (Bompa, 2015, p 14). When an athlete is developing strength, then the athlete may experience a positive transfer of power or endurance. 
According to Bompa (2015, p.13), "the development of dominant biomotor capabilities may possibly create a positive transfer of other biomotoric capabilities".

Variations of hand position in the current push-up has started many and developed. On this occasion researchers are interested in choosing wide push-ups and narrow push-ups. Narrow push-ups are done with the position of both palms pressed together. According to Marcolin (2015, p.1168), "Narrow push-up elicited greater activation for both the triceps brachii and pectoralis major muscles". Instead Wide push-up is done by opening the width of both hands until the elbow position to form a 90 degree angle. According to Marcolin (2015, p.), "Changing the position of the hands forward or backward can increase the electromyographic activity of the abdominal and back muscles". Both exercises are aimed at the same that is to train the arm muscles and have the same properties that are both lifting weights.

Based on the results of research conducted by Firmansyah (2016) which concluded that, "push-up exercises can increase power and power significantly". And according to Contreras (2014, p.7), "push-ups are widely used to develop upper body strength, power and muscular endurance". In addition, Allen (2013, p 278) says that "push-ups are a widely accepted means of assessing and improving upper body strength and endurance". From some of the above references the researchers concluded that push-ups can increase strength, power, and endurance in the upper body and push-ups are still popular and are often used in current physical exercise.

In this case researchers are encouraged to examine the wide push-up and narrow push-up exercises to determine the effectiveness of the exercise through a study, so it can be known and become an evaluation for the sport that achieves a better achievement later. Because it can not be denied that the physical conditions affect the achievements in the field of sports.

\section{METHODOLOGY}

The type of research used in this study is quantitative with quasi experimental method (Quasi Experiment) because it seeks a causal relationship between two variables. Experimental research is a rigorous study to determine the causal relationships between variables and by quasi-experimental methods so to know the causal relationships involve the control group in addition to the experimental group.

The design used to group research subjects is Matching-Only Design. In this design there are three groups, namely two experimental groups and one control group. The experimental group was the group that received Wide Push-Up and Narrow Push-Up treatment, while the control group was the teratment group but did the school activities or sports activities in the school (conventional). Furthermore, the three groups were given a pretest to determine the initial state 
whether there is a difference between the experimental group and the control group. Good pretest results when the experimental group values did not differ significantly with the control group. The design is described as follows:

\section{Table 1. Research Design}

\begin{tabular}{|c|c|c|c|c|c|c|c|}
\hline \multirow[t]{3}{*}{ us } & & \multirow[b]{3}{*}{ ठิ } & $\begin{array}{l}\text { Experimental group } \\
1\end{array}$ & T11 & $\mathrm{X} 1$ & $\mathrm{~T} 21$ & \multirow[b]{3}{*}{2} \\
\hline & \multirow[b]{2}{*}{$\stackrel{s}{2}$} & & $\begin{array}{l}\text { Experimental group } \\
2\end{array}$ & T12 & $\mathrm{X} 2$ & T22 & \\
\hline & & & Control group & $\mathrm{T} 23$ & - & T23 & \\
\hline
\end{tabular}

Research design (Maksum 2012)

Information:

S: Subject

Pre: Pretest

OP: Ordinal Pairing

T11: Experiment Group 1,

T21: Postest experimental group 1,

T12: Experiment Group 2,

T22: Postest experiment group 2,

T13: Control group without treatment

T23: Postest control group without treatment

$\mathrm{X} 1$ : Treatment exercises (wide push-up)

$\mathrm{X} 2$ : Treatment exercises (narrow push-up)

-: No treatment (but received training according to thetraining given by the teacher)

PT: Post-test

Independent variables, including wide push-up and narrow push-up exercises. While the dependent variable includes strength, power, and endurance arm muscle power. The population used in this researchwas all male students of class XI IPA in SMA Negeri 1 SumberrejoBojonegoro as many as 60 students. This research is a population research because the entire population is sampled so that the population research is called 60 samples. For sample grouping this research using ordinal pairing technique, with objective that each group have same ability quality. Ordinal pairing is a way to classify a sample based on the resulting ranking when performing a pretest. Types of tests used to measure strength that is expanding dynamometer, measure power that is medicine ball, while to measure endurance that is standart push-up for 60 seconds. These measurements were made to all sample groups during pretest and posttest. 
The data collected were analyzed descriptively and inferentially, to determine the category and to draw conclusions, in describing the results of the research used descriptive statistical calculations such as mean, standard deviation, variant, the lowest value and the highest value of the data collection. Then the means will be compared using independent t-test. Prior to the independent t-test, normality test with Kolmogorov-smirnov and homogeneity test using Anova was performed. The level of significance used in this researchwas 0.05 for data processing using computer SPSS.

\section{RESEARCH RESULT}

\section{Data Description}

In the wide push-up exercise group (experimental group I) showed that there was an increase in posttest average values on the dependent variable (strength, power, and endurance). The average strength rating of the posttest measurement of $15.35 \mathrm{~kg}$ shows an increase of pretest of 12.55 kgifconverted into percentage form then the percentage of strength increases by $22.31 \%$. Then the data acquisition power, showing the average value of speed shows an increase from the pretest data 160.10 joules to 177.02 joules in the posttest dataifconverted into percentage form then the percentage of power increases by $10.57 \%$. Furthermore, there is also an increase in average yield on endurance from pretest value of 17,60 to 20,60 in posttestifconverted into percentage form then the percentage of endurance increases by $17.05 \%$.

For more details it will display the increased strength, power, and endurance in the experimental group I in the form of diagrams.

\section{Figure1. Diagram of pretest and posttest results of experimental group I}

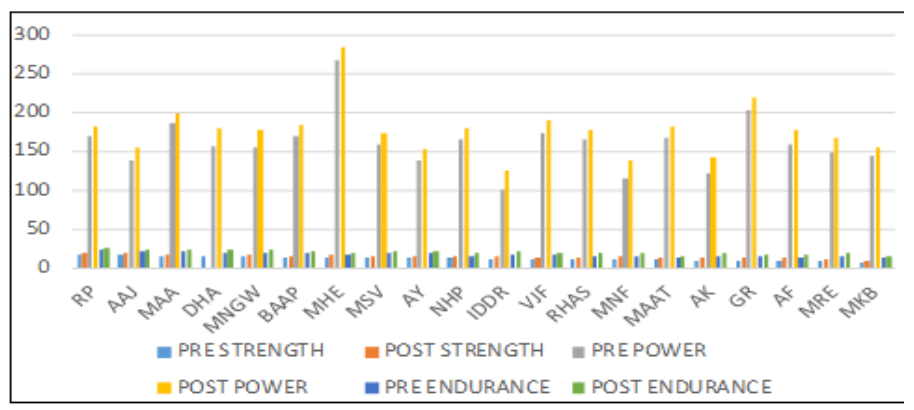

In the narrow push-up exercise group (experimental group II) shows that there is an increase in the average value of each dependent variable (strength, power, and endurance). The average value of strength shows an increase from the pretest value of $12.55 \mathrm{~kg}$ to $16.2 \mathrm{~kg}$ at the posttest valueifconverted into percentage form then the percentage of strength increases by $29.08 \%$. Then the average value on power also shows an increase from 155.64 joules at the pretest value increased 
to 183.56 joules at the posttest valueifconverted into percentage form then the percentage of power increases by $17.93 \%$. Furthermore, on endurance also showed an increase from the original value of pretest 17.9 increased to 21.55 at posttest valueifconverted into percentage form then the percentage of endurance increases by $20.39 \%$.

For more details it will display the increased strength, power, and endurance in the experimental group II in the form of diagrams.

\section{Figure 2. Pretest and posttest result of experimental group II}

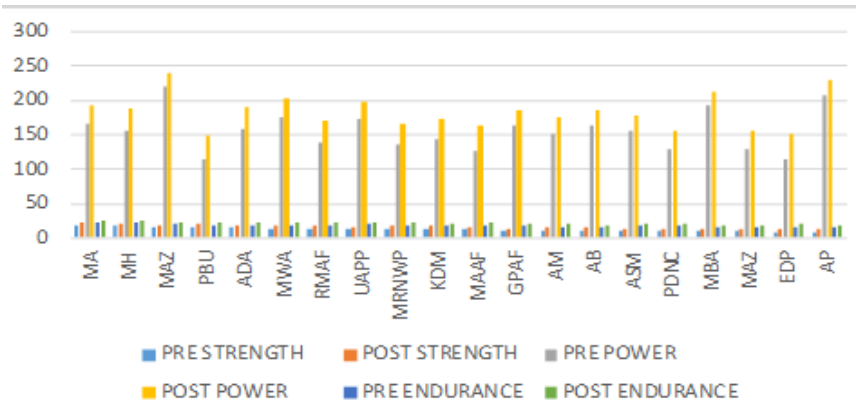

In the control group (experimental group III)showed an increase in mean value on the dependent variable strength, power, and endurance. At a pretest average the strength of $12.6 \mathrm{~kg}$ has increased to $13.35 \mathrm{~kg}$ at the posttest valueifconverted into percentage form then the percentage of strength increases by $5.95 \%$. Next to the average power value, the pretest value of 159.71 joules increased to 164.09 joulesifconverted into percentage form then the percentage of power increases by $2.75 \%$. Then the measurement result on the average value of the endurance variable shows the pretest value of 17.75 has increased to 18.6 on the posttest valueifconverted into percentage form then the percentage of endurance increases by $4.79 \%$.

For more details it will display the increased strength, power, and endurance in the experimental group III in the form of diagrams.

\section{Figure 3. Pretest and post-test results of the control group}

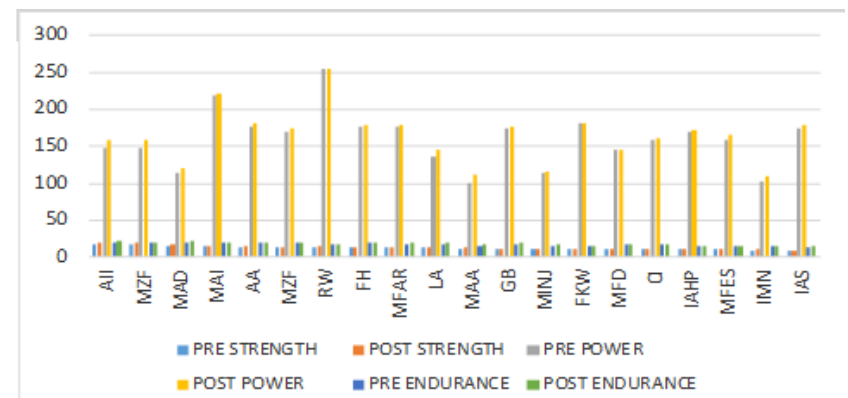


The data analysis consisted of Normality Test and Hypothesis Test, namely:

\section{Normality Test.}

The tested data was known that the data acquisition from three dependent variables namely strength, power, and endurance were normally distributed. This is because the significance or probability value of each group shows (p) or sig> 0.05 so that $\mathrm{HO}$ is accepted. This means that data is drawn from normally distributed populations.

\section{Table 2. Tests of Normality}

\begin{tabular}{ccccccc}
\hline Variabel & Tes & Kel.1 & Kel.2 & \multicolumn{1}{c}{ Kel.3 } & \multicolumn{1}{c}{ Ket } & Status \\
\hline \multirow{2}{*}{ Kekuatan } & & Sig & Sig & Sig & & \\
& Pretest & 0,155 & 0,200 & 0,149 & & \\
& Posttest & 0,200 & 0,200 & 0,085 & & \\
\multirow{3}{*}{ Power } & Pretest & 0,055 & 0,200 & 0,078 & & \\
& Posttest & 0,058 & 0,200 & 0,058 & & \\
& & & & & & \\
\multirow{2}{*}{ Endurance } & Pretest & 0,125 & 0,200 & 0,127 & & \\
& Posttest & 0,190 & 0,200 & 0,051 & & \\
\hline
\end{tabular}

\section{Homogeneity Test}

The data of the two dependent variables namelystrength, power, and endurance has homogeneous variance. This is because the significance value of each data is greater than the level of significance or $(p)>0.05$. So it can be stated that the variance in each group was the same or homogeneous

Table 3. Results of VarianceHomogeneity Test

\begin{tabular}{clccc}
\hline Variabel & Tes & Sig (p) & Ket & Status \\
\hline \multirow{2}{*}{ Kekuatan } & Pretest & 0,977 & & \\
& Posttest & 0,596 & & \\
\multirow{2}{*}{ Power } & Pretest & 0,714 & $\mathrm{P}>0,05$ & Homogen \\
& Posttest & 0,682 & & \\
Endurance & Pretest & 0,483 & & \\
& posttest & 0,432 & & \\
\hline
\end{tabular}

The following will be presented the results of the Post Hoc test with LSD and mean plots. 


\begin{tabular}{|c|c|c|c|c|c|c|}
\hline \multirow[b]{2}{*}{$\begin{array}{l}\text { (I) } \\
\text { KELOMPOK }\end{array}$} & \multirow[b]{2}{*}{$\begin{array}{l}\text { (J) } \\
\text { KELOMPOK }\end{array}$} & \multirow{2}{*}{$\begin{array}{c}\text { Mean } \\
\text { Difference } \\
(1-J)\end{array}$} & \multirow[b]{2}{*}{$\begin{array}{l}\text { Std. } \\
\text { Error }\end{array}$} & \multirow[b]{2}{*}{ Sig. } & \multicolumn{2}{|c|}{$\begin{array}{c}95 \% \text { Confidence } \\
\text { Interval }\end{array}$} \\
\hline & & & & & $\begin{array}{l}\text { Lower } \\
\text { Bound }\end{array}$ & $\begin{array}{l}\text { Upper } \\
\text { Bound }\end{array}$ \\
\hline KELOMPOK & KELOMPOK & & & & & \\
\hline WIDE & NARROW & $-1,00000$ &, 91474 &, 029 & $-2,8317$ &, 8317 \\
\hline \multirow[t]{2}{*}{ PUSH UP } & PUSH UP & & & & & \\
\hline & KONTROL & $1,85000^{\circ}$ &, 91474 &, 048 & ,0183 & 3,6817 \\
\hline KELOMPOK & KELOMPOK & & & & & \\
\hline NARROW & WIDE PUSH & 1,00000 &, 91474 &, 029 &,- 8317 & 2,8317 \\
\hline \multirow[t]{2}{*}{ PUSH UP } & UP & & & & & \\
\hline & KONTROL & $2,85000^{\circ}$ &, 91474 &, 003 & 1,0183 & 4,6817 \\
\hline \multirow[t]{6}{*}{ KONTROL } & KELOMPOK & & & & & \\
\hline & WIDE PUSH & $-1,85000^{\circ}$ &, 91474 &, 048 & $-3,6817$ &,- 0183 \\
\hline & UP & & & & & \\
\hline & KELOMPOK & & & & & \\
\hline & NARROW & $-2,85000^{\circ}$ & ,91474 &, 003 & $-4,6817$ & $-1,0183$ \\
\hline & PUSH UP & & & & & \\
\hline
\end{tabular}

From table 4 above, it can be concluded that there was a significant differences between groups. The difference can be seen in the mean difference column. The above-mentioned mean difference column showed evidence that there is an effect on increasing strength between the studied groups. This can be known from the mean difference value, that the experimental group II is more optimal in increasing strength compared to the experimental group I and the control group. This is because the best value for narrow push-up is the greatest value (maximum).

The statement is clarified in the mean strength plots, which show a greater increase in the push-up narrow practice method.

\section{Figure 4. Mean Plots Strength}

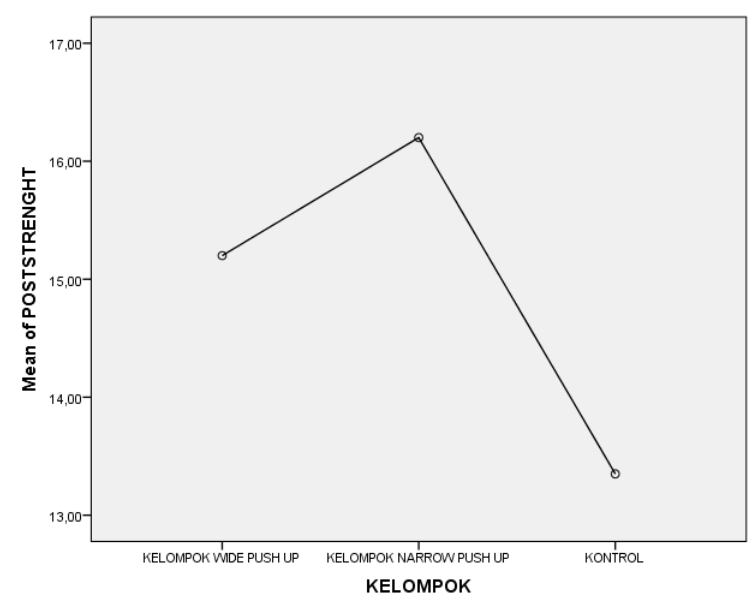




\section{Table 5. Post-Hoc Test Results with LSD of Power Variable}

\begin{tabular}{|c|c|c|c|c|c|c|}
\hline \multirow[b]{2}{*}{ (l) } & \multirow[b]{2}{*}{$(\mathrm{J})$} & \multirow{2}{*}{$\begin{array}{c}\text { Mean } \\
\text { Difference }\end{array}$} & \multirow[b]{2}{*}{ Std. } & \multirow[b]{2}{*}{ Sig. } & \multicolumn{2}{|c|}{$\begin{array}{c}95 \% \text { Confidence } \\
\text { Interval }\end{array}$} \\
\hline & & & & & $\begin{array}{l}\text { Lower } \\
\text { Bound }\end{array}$ & $\begin{array}{l}\text { Upper } \\
\text { Bound }\end{array}$ \\
\hline \multicolumn{7}{|c|}{ KELOMPOK KELOMPOK } \\
\hline WIDE & NARROW & $-6,54450$ & 9,96835 &, 014 & $-26,5058$ & 13,4168 \\
\hline \multirow[t]{2}{*}{ PUSH UP } & PUSH UP & & & & & \\
\hline & KONTROL & 12,92150 & 9,96835 &, 020 & $-7,0398$ & 32,8828 \\
\hline KELOMPOK & KELOMPOK & & & & & \\
\hline NARROW & WIDE PUSH & 6,54450 & 9,96835 &, 014 & $-13,4168$ & 26,5058 \\
\hline \multirow[t]{2}{*}{ PUSH UP } & UP & & & & & \\
\hline & KONTROL & 19,46600 & 9,96835 &, 046 &,- 4953 & 39,4273 \\
\hline \multirow[t]{5}{*}{ KONTROL } & KELOMPOK & & & & & \\
\hline & $\begin{array}{l}\text { WIDE PUSH } \\
\text { UP }\end{array}$ & $-12,92150$ & 9,96835 &, 020 & $-32,8828$ & 7,0398 \\
\hline & KELOMPOK & & & & & \\
\hline & NARROW & $-19,46600$ & 9,96835 &, 046 & $-39,4273$ & ,4953 \\
\hline & PUSH UP & & & & & \\
\hline
\end{tabular}

From table 5 above, it can be concluded that there was a significant differences between groups. The difference can be seen in the mean difference column. The above-mentioned mean difference column showed evidence that there is an effect on increasing power between the studied groups. This can be known from the mean difference value, that the experimental group II is more optimal in increasing power compared to the experimental group I and the control group. This is because the best value for narrow push-up is the greatest value (maximum).

The statement is clarified in the mean power plots, which show a greater increase in the push-up narrow practice method.

\section{Figure 5. Mean Plots Power}

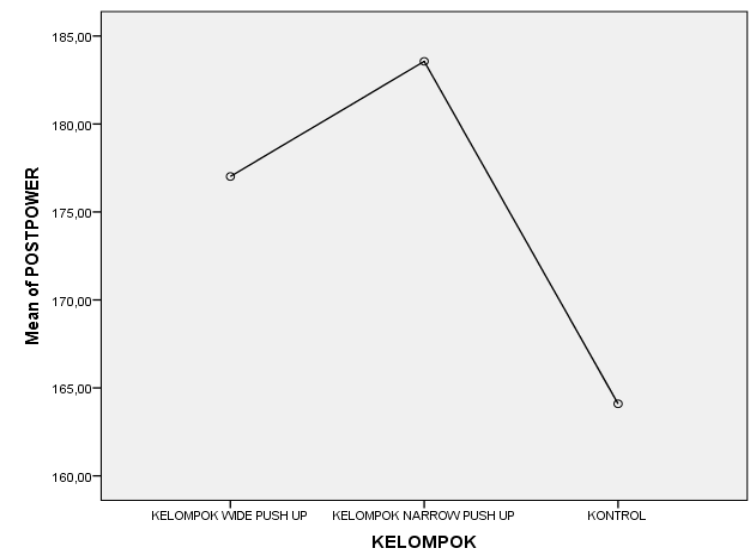


Table 6. Post-Hoc Test Results with LSD of Endurance Variable

\begin{tabular}{|c|c|c|c|c|c|c|}
\hline \multirow[b]{2}{*}{ (I) } & & \multirow{2}{*}{$\begin{array}{c}\text { Mean } \\
\text { Difference } \\
(1-J) \\
\end{array}$} & \multirow[b]{2}{*}{$\begin{array}{l}\text { Std. } \\
\text { Error }\end{array}$} & \multirow[b]{2}{*}{ Sig. } & \multicolumn{2}{|c|}{$\begin{array}{c}95 \% \text { Confidence } \\
\text { Interval }\end{array}$} \\
\hline & $\begin{array}{l}(\mathrm{J}) \\
\text { KELOMPOK }\end{array}$ & & & & $\begin{array}{l}\text { Lower } \\
\text { Bound }\end{array}$ & $\begin{array}{l}\text { Upper } \\
\text { Bound }\end{array}$ \\
\hline \multicolumn{7}{|c|}{ KELOMPOK KELOMPOK } \\
\hline WIDE & NARROW & $-1,05000$ &, 77091 &, 019 & $-2,5937$ & , 4937 \\
\hline \multirow[t]{2}{*}{ PUSH UP } & PUSH UP & & & & & \\
\hline & KONTROL & $1,90000^{\circ}$ &, 77091 &, 017 &, 3563 & 3,4437 \\
\hline KELOMPOK & KELOMPOK & & & & & \\
\hline NARROW & WIDE PUSH & 1,05000 &, 77091 &, 009 &,- 4937 & 2,5937 \\
\hline \multirow[t]{2}{*}{ PUSH UP } & UP & & & & & \\
\hline & KONTROL & $2,95000^{\circ}$ &, 77091 &, 000 & 1,4063 & 4,4937 \\
\hline \multirow[t]{6}{*}{ KONTROL } & KELOMPOK & & & & & \\
\hline & WIDE PUSH & $-1,90000^{\circ}$ &, 77091 &, 017 & $-3,4437$ &,- 3563 \\
\hline & UP & & & & & \\
\hline & KELOMPOK & & & & & \\
\hline & NARROW & $-2,95000^{\circ}$ &, 77091 &, 000 & $-4,4937$ & $-1,4063$ \\
\hline & PUSH UP & & & & & \\
\hline
\end{tabular}

From table 6 above, it can be concluded that there was a significant differences between groups. The difference can be seen in the mean difference column. The above-mentioned mean difference column showed evidence that there is an effect on increasing endurance between the studied groups. This can be known from the mean difference value, that the experimental group II is more optimal in increasing endurance compared to the experimental group I and the control group. This is because the best value for narrow push-up is the greatest value (maximum).

The statement is clarified in the mean endurance plots, which show a greater increase in the push-up narrow practice method.

\section{Figure 6. Mean Plots Endurance}

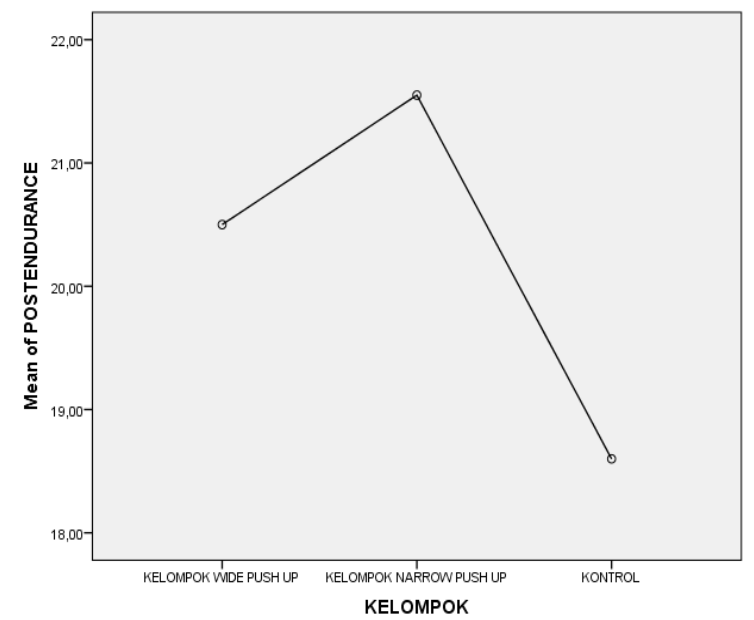




\section{DISCUSSION}

Based on the observation and treatment of wide push-up group, there is an increase of average in almost all aspects of physical condition that have been determined in this study. The average increase occurred on the strength variable of $22.31 \%$ or $2.65 \mathrm{~kg}$, the increase in power of $10.57 \%$ or 16.92 Joules, and an increase in endurance of $17.05 \%$ or 3.65 times.

While on the statistical results with different test, a significant increase occurred in all aspects of physical conditions that have been determined also on the strength, power, and endurance. On the power indicates the sig value. ( 2 tailed $)=$ $0,000$, power shows sig value. ( 2 tailed $)=0,000$, and endurance shows sig value. ( 2 tailed $=0,000$. So it can be concluded Ho rejected and Ha accepted, because the value of Sig. 0,000 is smaller than value of $\alpha$ is 0.05 .

Wide push-up exercises have a significant effect on the strength, power, and endurance of arm muscles because they constantly perform contractions during the exercise. When performing wide push-ups, the dominant muscles contracting are anterior deltoids, pectoralis major, anterior serratus, triceps brachii, and rectus abdominis. By exercising these muscles with wide-ranging 6-week wide push-up exercise with exercise frequency 3 times a week according to the power endurance training program with individual principles. Thus the arm muscle is required to work hard and continuously so that in addition to increasing strength and power there is also an increase in the aspect of endurance.

From a literature review of significant improvements in wide-push exercises, researchers found that it was in accordance with Contreras (2014, p.202) suggesting that wide push-up is a push-up technique that can be used to improve muscle strength in the arm. Plus a journal from Sorace (2012, p.45) that push-ups can be an excellent exercise to increase muscle strength and endurance. In addition, results of similar research belonging to Renditya Prima Putra (2014) and Firmansyah (2016) are push-up exercises with other variations such as T push-ups and crocodile push-ups there is a significant influence on the strength and power of arm muscles. So when compared with $\mathrm{T}$ push-ups and crocodile push-ups, in addition to a significant effect on strength and power, wide push-up exercises also have a significant effect on arm muscle endurance.

Based on the observation and treatment of the narrow push-up group, there was an increase in average in almost all aspects of physical condition that have been determined in this study. The average increase in power variables of $29.08 \%$ or $3.65 \mathrm{~kg}$, an increase in power of $17.93 \%$ or 27.91 Joule, and an increase in endurance of $20.39 \%$ or 3.65 times. While on the statistical results with different test, a significant increase occurred in all aspects of physical conditions that have been determined also on the strength, power, and endurance. On the power indicates the sig value. ( 2 tailed $)=0,000$, power shows sig value. ( 2 tailed $)=$ $0,000$, and endurance shows sig value. ( 2 tailed $)=0,000$. So it can be concluded Ho rejected and Ha accepted, because the value of Sig. 0,000 is smaller than value 
of $\alpha$ is 0.05 .

Narrow push-up exercise has a significant influence on the strength, power, and endurance of the arm muscles because the muscles constantly perform contractions continuously during the exercise. At the time of narrow push-ups, the dominant muscles contracting are trapezius, serratus anterior, anterior deltoid, triceps brachii, and rectus abdominis. By exercising these muscles with wideranging 6-week wide push-up exercise with exercise frequency 3 times a week according to the endurance power training program with individual principles. Thus the arm muscle is required to work hard and continuously so that in addition to increasing strength and power there is also an increase in the aspect of endurance.

From a literature review conducted on a significant increase in the push-up narrow practice, the researchers found that it was in accordance with Contreras (2014, p.202) suggesting that this narrow pushup is a push-up technique that can be used to improve muscle strength in the arm. Plus a journal from Sorace (2012, p.45) that push-ups can be an excellent exercise to increase muscle strength and endurance. In addition, results of similar research belonging to Renditya Prima Putra (2014) and Firmansyah (2016) are push-up exercises with other variations such as T push-ups and crocodile push-ups. There is a significant influence on the strength and power of arm muscles. So when compared to $\mathrm{T}$ push-ups and crocodile push-ups, in addition to a significant effect on strength and power, the push-up narrow exercises also have a significant effect on arm muscle endurance.

So it can be concluded that push-up training is an effective training to increase strength, power, and endurance. So it can be used as a reference in exercises to increase the strength, power, and endurance of the arm muscles, especially narrow push-up exercises.

\section{CONCLUSION}

Based on the results of research and previous discussions, it will be described the following conclusions:

1. There is a significant effect of wide push-up exercises on increasing strength, power, and endurance.

2. There is a significant effect of narrow push-up exercises on increasing strength, power, and endurance.

3. There is a significant difference of influence between wide push-up and narrow push-up exercises for increased strength, power, and endurance.

\section{Suggestion}

Based on the results obtained after conducting research, some suggestions that can be submitted by researchers are:

1. Further research on wide push-up and narrow push-up exercises with different exercise variations and sample conditions is required. 
2. For coaches to prepare an exercise program to provide a variety of exercises so that athletes do not feel bored, do not quickly experience fatigue and spirit in the exercise to get maximum results.

3. In preparing an exercise program the trainer should consider the characteristics of each athlete, as each athlete has a different character in responding to each exercise program, so that the athlete is able to exercise maximally and achieve the training objectives.

4. It is recommended that push-up exercises such as wide push-ups and narrow pushups can be applied to training programs aimed at enhancing strength, power and endurance.

\section{REFRENCES}

Allen, Caroline, C., Dean, Katie, A., Jung, Alan, P., Petrella, John, K. (2013).Upper Body Muscular Activation during Variations of Push-Ups inHealthy Men. International Journal Of Research And Applied Studies6(4), 278-288.

Baechle, T. R. and Earle, R. W. (2012). Fitness Weight Training. United States: Human Kinetics.

Bazyler, Caleb, D., dkk. (2015). Strength Training for Endurance Athletes:Theory to Practice. Department of Exercise and Sport Science. 37(2), 1-12.

Black, E. K., Skidmore, Paula, M.L., and Brown, Rachel, C. (2012). EnergyIntakes of Ultra Endurance Cyclists During Competition, anObservational. International Journal of Sport Nutrition and ExerciseMetabolism. 8(6), 225

Bompa, T. O., \& Carlo Buzzichelli. (2015). Periodization training for sports. Third Edition, United States: Human Kinetics.

Budiwanto, Setyo. (2012). Metodologi Latihan Olahraga. Malang: PenerbitUniversitas Negeri Malang (UM PRESS).

Christina, Sasminanta. (2013). Materi Ilmu Kepelatihan Dasar. Surabaya:Universitas Negeri Surabaya.

Contreras, Bret. (2014). Bodyweight, strength training anatomy. United States:Human Kinetics.

Elsayed, Mohammed. (2012). Effect of Plyometric Training on Specific PhysicalAbilities in Long Jump Athletes. International Journal of Research AndApplied Studies. 7(2), 105-108.

Fatah, Nurdin. dan Aisyah, Kemala. (2012). Kekuatan Otot Lengan Atlet AtletikPPLP (Pusat Pendidikan Latihan Pelajar) DKI Jakarta. Gladi Jurnal IlmuKeolahragaan. Vol 6 No.1

Fenanlampir, Albertus. Faruq, Muhammad, Muhyi. (2015). Tes \& PengukuranDalam Olahraga. Yogyakarta: Andi OFFSET.

Firmansyah. (2016). Pengaruh Latihan Crocodile Push-up dan T PushupTerhadap Kekuatan Otot Lengan dan Power Otot Lengan. (Tesis yang tidak dipublikasikan), Universitas Negeri Surabaya, Surabaya.

Haff, G. Gregory. and Nimphius, Sophia. (2012). Training Principles forPower. Centre for Exercise and Sport Science Research. 34(6),2-12. 
Helen, M. Binkley. (2014). Strength, Size or Power. NCSA's PerformanceTraining. International Journal Of Strength And Conditioning Research1(4).

Kenney, Larry. Jack, H. Wilmore, \& David L. Costill. (2012). Physiology ofsport and exercise. Fifth Edition. United States: Human Kinetics.

Kusnanik, N. W., Nasution, J., \& Hartono, S. (2011). Dasar-dasar fisiologiolahraga. Surabaya: UNESA University Press.

MacKenzie, Brian. Cordoza, Glen. (2012). Power Speed Endurance: A SkillBased Approach to Endurance Training. Victory Belt Publishing.

Maksum, Ali. (2012). Metodologi Penelitian dalam Olahraga. Surabaya: UnesaUniversity Press.

Marcolin, Giuseppe. Petrone, Nicola. Moro, Tatiana. Battaglia, Giuseppe. Bianco, Antonino. Paoli, Antonio. (2015). Selective Activation of Shoulder, Trunk, and Arm Muscles: A Comparative Analysis of Different Push-Up Variants. Journal of Athletic Training. 50(11), 1126-1132

Mylsidayu, Apta. Kurniawan, Febi. (2015). Ilmu Kepelatihan Dasar. Bandung:Alfabeta.

Nurhasan. (2011). Menjaga Kebugaran Jasmani. Gresik Jawa Timur: AbilPustaka.

Ozgur, Turgay. (2012). Muscle Power And Strength Performance In Sport.International Journal of Basic and Clinical Studies (IJBCS). 1(2),4155.

Putra, Renditya, Prima. (2014). Pengaruh Latihan T Push-up dan Crocodile Pushup Terhadap Power Otot Lengan dan Kekuatan Otot Lengan Pada SiswaPutra SMP Negeri 3 Kota Kediri. (Tesis yang tidak dipublikasikan),Universitas Negeri Surabaya, Surabaya.

Ratamess, Nicholas. (2012). ACSM's foundations of strength training andconditioning. Indianapolis. Lippincott Williams \& Wilkins.

Sorace, Paul. (2012). The Biomechanics of the Push-up: Implications forResistance Training Programs. International Journal Of Strength AndConditioning Research. 34(5), 41-46.

Sukadiyanto \& Muluk. (2011). Pengantar Teori dan Metodologi Melatih Fisik.Bandung: CV. Lubuk Agung.

Suprak, David N. and Stephenson, Mark, D. (2011). The Effect Of Position OnThe Percentage Of Body Mass Supported During TraditionalandModified Push-Up Variants. Journal Of Strength And ConditioningResearch. 25(2), 497-503.

Universitas Negeri Surabaya. (2015). Pedoman Penulisan Tesis dan Disertasi.Surabaya: Program Pascasarjana Universitas Negeri Surabaya.

Undang-Undang Republik Indonesia No. 3. (2005). Sistem KeolahragaanNasional. Jakarta: Presiden Republik Indonesia.

Venkatachalapathy, V., Ibrahim, Sheriff, K. R. Asghar Nikseresht. (2015).Effect Of Circuit Training Programme On Speed And Agility.International Journal Of Research And Applied Studies. 2(17), 71-72

Wade, Paul. Jones, Brett. Shank, Max. (2012). Convict Conditioning: The prison push-up series. United States: Dragon Door Publications.

Werner, W. K. H., and Sharon, A. H. (2011). Principles and Labs for PhysicalFitness. United State of America: Wadsworth.

Widiastuti. (2011). Tes dan Pengukuran Olahraga. Jakarta: PT Bumi Timur Jaya. 